sense of humour, and deep appreciation of ' the courage and often heroism with which many of the victims of injury and disease have met their misfortune' so that the reader closes the book affirming the verdict of its Foreword-'She has an enthralling tale to tell'.

\section{Good English for Medical Writers}

Ffrangcon Roberts, M.A., M.D., F.F.R. Pp. ix + 179. London: William Heinemann. 1960. I7s. $6 d$.

A book to help medical authors to write better English is badly needed, and it is surprising that so few books of this kind have been written. Presumably few people dare face the risks which Dr. Ffrangcon Roberts mentions at the end of his introduction (p. 6). ' I quite expect readers to point the finger of scorn at me when they discover, as they certainly will, that I have myself committed many of the sins that I condemn'.

This disarming admission makes it seem churlish to look too closely at the occasional blemishes, but it is disconcerting to find on the third page of a book which sets out to show you how to say exactly what you mean, a sentence which fails as flagrantly as, "A single number of the British Medical Fournal contains about 100,000 words or about $5,000,000$ in the course of a year'.

The book is a well-meant attempt to do something that badly needs doing, and the principles set out on page 7 are admirable: ' To achieve clarity you must attend to four things, you must be brief, you must choose the words that most accurately express your meaning, you must observe the rules of grammar, and you must arrange the words according to their relative importance'.

Yet the book is disappointing because it does not give medical writers the help they badly need. Anyone who tells you ' how to do it' must be very careful that he does it pretty well himself; the demonstration by the instructor is watched closely by his pupils and critics. Here the instructor does not perform well enough to give the readers confidence or to protect himself from critical scrutineers. The motes $\mathrm{Mr}$. Roberts finds in his brothers' pens seem small when larger motes are left untouched, and when there are quite a lot of beams in his own pen.

There are too many defects in both the style and the substance of the book. The style is turgid and woolly. When the author wants to say that during the last 6o years Western people have advanced further in knowledge than ever before, he writes (p. 57): 'After remaining almost static for several centuries, Western civilization has entered upon a period of ever-growing dynamism ', and when he wishes to explain that the standard of medical writing is not deteriorating, he puts it thus: "Taking these facts into consideration, it would, I think, be difficult to make out that any literary deterioration has taken place'.

Dr. Ffrangcon Roberts rightly cautions us to avoid words such as 'horribly' or 'terribly', because by showing our feelings too obviously, they weaken our argument; but he weakens his own argument by calling words which show your feelings, 'words signifying subjective impressions' and by his own use of emotionally toned words, for instance 'the sooner the ghastly remains return to the grave the better' (of serendipity, p. 147) and 'this monstrous pompous bastard' (of armamentarium, p. I8).

In many places the author gives you the feeling he is out to show you how badly you do it, rather than help you to do it well, and the large number of minor offenders that are pilloried strengthens this impression. The word 'moon-like' to describe a face receives the comment: "What kind of moon-new, half, or full' (sic, no question mark). 'Dysarthria' is criticized because the word might get confused with arthritis. $C$ To use the word electroplexy instead of electric shock is classed as " sheer pedantry, and cannot be too strongly, condemned'. Surely 'moon-like' and 'dysarthria '음 cause little confusion, and most people think of an $\frac{\bar{\sigma}}{\sigma}$ electric shock as a frightening, painful thing, whereas $\overline{\bar{c}}$ electroplexy causes no pain but produces unconscious- $\frac{\rho}{T}$ ness and amnesia. Criticizing established words gives $\mathbb{\Phi}$ no help to writers, for such words have come to stay, however faulty their origins. For example, 'hæmo- $\infty$ philia '- no term could be more absurd. A better $\vec{\circ}$ word would be hæmapexia '; 'tetralogy '-' the proper'meaning of tetralogy is a group of four discourses. $\vec{\omega}$ A better word would be tetrad'. These comments do. not help authors.

Ideally, medical writing should be so clear that there is no chance of it being misunderstood, but several passages in this book are far from this standard. On p. 126 we read: "The association of angina with throm-is bosis of the coronary arteries gave it the name coronary thrombosis. Exophthalmic goitre described two of the prominent characteristics-protrusion of the eyes and $N$ enlargement of the thyroid'. On the same page we ${ }^{\infty}$

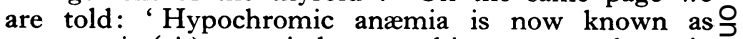
macrocytic (sic) anæmia because this expresses the main feature of the disease'. Not only is that entirely $\square$ incorrect, but it also suggests that a term denoting the size of a cell can replace one describing the depth of its colour, which it could never do because these things $\vec{\theta}$ vary independently. Lack of elementary hæmatologiogl knowledge is also shown by the passage (p. 36): "Bis. trinsic is the opposite of intrinsic and means adves titious or not essential '. Though that is one of the meanings listed by the dictionary, it is hardly the one to choose when the medical use of the adjective is commonly attached to a substance essential to life.

There is a confusing passage on p. I ro: "Here is $\frac{\mathbb{Q}}{\mathbb{Q}}$ Case X from the Third Book on Epidemics (by Hippocrates). As was to be expected from so distinguished a scholar, the translation* is accurate and literal'. 3

A similar piece of muddled writing occurs on $p$. 15, where we are told: "Apart from colloquialisms and technical terms, the fact that you are writing on a medical subject does not justify you in adorning that $\frac{}{3}$ subject with words that you would not dream of using in ordinary speech'. Presumably that means you can $\bar{\sigma}$ use the idiom of normal speech for medical articles apart from colloquialisms, and that you can keep to $\bar{\partial}$ that idiom apart from a few technical terms. It is puzzling to have exceptions of exclusion and exceptions of inclusion in one sentence; it seems like saying, 음 'Invalid diet should be much the same as ordinary $D$ food apart from Benger's Food and pickled whelks'.

An odd blunder for an experienced writer to make is: "Inverted commas enclose quotations or " quotes" N as they are technically called'. The technical sense of 'quotes' when used by printers and publishers is $N$ ' inverted commas' as in 'single quotes' or 'double స్ quotes'.

In short, this book has too many faults and gives too little help for it to be recommended to aspiring medicalo authors.

*Translated by W. H. S. Jones. Who is the distinguished scholar? Hippocrates or Jones? is the 